\title{
Social Values of Antiquities in Bulgaria: Anthropological Perspectives
}

\author{
Tsvete Petrova Lazova \\ New Bulgarian University, Department of Anthropology
}

Received 30 March 2018 • Revised 29 June 2018 • Accepted 18 July 2018

\begin{abstract}
This article analyses some aspects of the processes constructing values of the remote past and their role in the formation of national identity. The useful debate on "identity" provides a space to look at it not only as an analytical category but also as a practical one. As a category of practice it is concerned to be used by "lay" actors in some everyday settings to make sense of themselves and how they differ from others (Brubaker \& Cooper, 2000). I focus therefore on antiquities material and non-material artifacts - which play active role in everyday life as identity marker. They are seen as anthropological terrain where the "eye of anthropology" makes possible to evaluate the nature of discourses on antiquities as cultural products in the context of the imagined nation. This supposes to look not only at the rhetoric of the national(ist) discourse but also at its content. In a "longue durée" perspective it becomes possible to be traced the uses of antiquities in Bulgaria with its complexities and beyond the dynamics of transformations within the academic fields and their research agenda. This perspective is useful as it introduces the needed sensitivity to different intensities of nationalism across time and space as well as within the same space (Todorova, 2015). Rooted in Romanticism the academic and non-academic research practices of antiquities are coupled with the doctrines of cultural survivals and continuity of the 19th century and enriched by the German Altertumswissenschaft. These trends provide sound basis for the advent of the Soviet theory of ethnogenesis and thus the national continuum seems monolithic and never broken even by the strong political perturbations in 1944 (the beginning of the communist regime) and 1989 (the beginning of democratic changes) in Bulgaria. After the changes some archaeological sites interpreted through ancient Greek imageries entered the marketplace as culture-historical "authentic" heritage.
\end{abstract}

Keywords: antiquities, national identity, politics of the past, history of archaeology, uses of culture-historical approach, theory of ethnogenesis, production of antiquities.

\section{Introduction}

This text is based on a research project conducted in the Department of Anthropology at New Bulgarian University and published in 1916 (Lazova, 2016). Touching upon communities of people who are obsessed with the politics of the past the ethnographic writing as a method turned out as not always effective. The interviews concerning national past and its antiquity are saturated even polluted by ideological clichés produced mainly during the late socialism. It is therefore needed a contextualization of the archaeological practice studied by the fruitful approach called "archaeological ethnography". This research agenda pays attention to problems of how archaeological data of a site are acquired examining the social, political, and ideological contexts

(C) Authors. Terms and conditions of Creative Commons Attribution 4.0 International (CC BY 4.0) apply. Correspondence: Tsvete Petrova Lazova, Sofia 1330, JK Krasna Poliana III, 37A, vh. V. ap. 58, BULGARIA. E-mail: tlazova@gmail.com. 
in which it is produced. It is an approach that tends to be realized by a "thick description", concerning a very wide range of documentation including various descriptions, publications, tourist guides, media products, interviews with different participants in archaeological excavations, exhibitions, internet publications etc. (Hamilakis \& Anagnostopoulos, 2009). The approach evaluates the process of developing the site: how the knowledge about it is constructed, becomes popular, becomes integrated into national values and identity; how academics communicate with local experts to gain knowledge about ancient past; how this knowledge transmitted by different kind of media is internalized structuring our worldviews. Researching several case studies it became clear that antiquity is understood in terms of culture-historical methods focusing exclusively on historical "continuity" of an ethno-nation totality found on the territory of the modern Bulgarian state.

As a classical philologist my earlier studies were concerned with ancient texts as sources for Thracian history. It appeared however that the Thracians are viewed exclusively through Greek eyes therefore the notion of them is a matter of numerous speculative interpretations. A number of mythical figures (e.g. Orpheus) are represented as Greeks' notion of "otherness" and therefore mobilized by Bulgarian scholars to represent what might be isolated as non-Greek, i.e. Thracian. There is however no obvious and direct way to subtract a non-Greekness from ancient texts created in different contexts from different times. The absence of Thracian own literature and even script adds to the deficiencies in our knowledge about Thracians which generate speculations well serving national ideological projects. The serious shortcomings of the culture-historical method is therefore the inevitable binding together of archaeological materiality and ancient texts as interpretative instrument of the material data. Besides very few archaeological interpretations produced by more functionalist approaches in the context of some international projects, the culture-historical method is still omnipresent in Bulgaria.

The uses of culture-historical approaches are discussed in this text with the potentials of reflexive studies developed by anthropological discipline in the last few decades (Marcus \& Fisher, 1986). Anthropology as a cultural critic gave way to researching the processes of constructing and using antiquity by national(ist) projects. The archaeological practice apart from its highly specialized and technological occupation is seen now as an important social practice. The relations between nation, nation-states, nationalism and antiquities of different kind as identity markers entered comparatively late the anthropological fieldwork. The reason of this absence is explained as resulting from the discipline's concerns with "primitive" peoples or "nonstate" societies. Thus the topic of the nations was imagined as too "Western" and too macro for the anthropological attention (Samah, 2007). This shortage was very quickly compensated by linking nationalism to traditionally anthropological interests as kinship and religion. B. Anderson's imagined communities opened up new possibilities for anthropological studies of nationalism. As a benchmark in the study of nation and nationalism it reinforced the focus on nation-building and produced valuable insights.

Today, nationalism is analyzed in a multitude of studies and is grouped in several rubrics containing a variety of different qualifiers - diachronic, geographic/territorial, typological as civic, democratic, popular, populist to mention only few of them (Todorova, 2015: 681-699). Among these categories is the so called cultural nationalism. This category is rarely separately treated as it is considered to be framed with the modern nationalism as the interests in cultural matters often ensure useful screening of political battles (Hutchinson, 1994). The cultural nationalists are described as intellectuals - scholars and artists who "imagine" the nation as differentiated community, united not by law or reason, but by passionate sentiments rooted in nature and history. In many Balkan countries they are politicians as well. Their imagination constructs the nations as primordial expressions of "spirituality" extracted from ancient "ethnic" and "autochthonic" ancestry. It ensures "national specificity" and historical "continuity". The national intellectuals therefore combine a romantic search for meaning with scholarly 
methodology to establish a place for the nation in the civilized world. This quest has resulted in an explosion of research in sciences as archaeology, folklore, philology, topography. The aim of these ill-documented spheres is to recover the creative force of the national spirit from a cultural substratum (Hutchinson, 1994: 44-45). The success of their discourses is based mainly on outdated anthropological paradigm of cultural evolution with its doctrines of cultural survivals and cultural continuity (Danforth, 1984). The Balkan ethnologists are characterized also by a double insider syndrome as the ethnologist belongs to the group he studies, sharing its language, traditions, dominant values and interests i.e. he identifies himself with his object of study. His task is to consolidate and, if needed, to invent the identity of this group (Naumovich, 1998: 102).

The present text tends to add to the notion of cultural nationalism some valuable insights from the contemporary anthropology. The relevance of anthropology to the studies of nation-state and nationalism emphasizing its emotive power is revealed in Herzfeld's influential work on "cultural intimacy" (Herzfeld, 1997). It touches upon "the recognition of those aspects of a cultural identity that are considered a source of external embarrassment but that provide insiders with their assurance of common sociality" (Herzfeld, 1997: 3). The notion of "cultural intimacy" can be traced in many nation-states with a variety of ways studying the relations between state ideologies and the intimacy of everyday social life. I appreciate the way it is developed by a number of Bulgarian scholars (Detchev, 2010). Basing their studies on Herzfeld's "cultural intimacy" the authors specify it as processes of "intimization" of various practices and discourses in everyday life as symbolic for their present being. The intimization processes include various components of everyday life - language, dress, songs, houses, rituals etc. which in ideological contexts of nationalism they become "ours" and therefore "Bulgarian". The approach of searching the essentially Bulgarian characteristics through outlining networks of national intimacy widens the scope of Herzfeld's cultural intimacy. It gives the chance for many pieces from the past (in my case from the remote past) to become static and in this sense unchangeable in the national imagination. It is important to note here that reification is a social process, not only intellectual practice. As such it becomes central to the politics of "ethnicity", "race", "nation" and other putative identities. It is important to seek to an account for the processes of reification how the "political fiction" of the nation can crystallize at certain moments as a powerful compelling reality (Brubaker \& Cooper, 2000). Therefore, I expect to join antiquity as important addition to the networks of national intimacy constructing the intimate space of the national belonging revealed by the Bulgarian scholars.

The role of antiquity in constructing and legitimizing of national identity is a quite new topic for the Bulgarian scholarship. The study of ancient Thrace and the ideological aspects of its institutionalization as Thracology is critically viewed in a reflexive study which outlines the context of the shared, connected, and entangled history of the Balkans (Daskalov \& Vezenkov, 2015). It includes the study of ideological aspects of the construction of Thracian studies (Thracology) in Southeastern Europe which focuses on the modern imagination of antiquities in Bulgarian scholarship (Marinov, 2015: 10-117).

\section{Approaching the production of antiquity: culture-historical paradigm}

In Bulgaria, as in most European countries, especially in Southeastern Europe, studies in antiquity belong to the historical sciences. After the fall of the communist regime real opportunities appeared for the Bulgarian scholars to reappraise the methods of studying antiquity and to discard the ideological burden imposed on it by the communist past. By that time very few academics took the opportunity to analyze critically the historiographical tradition in Bulgaria and the contexts of its shaping. Born in the age of nationalism Bulgarian historiography was developing in the context of nation-state formation as one of its important pillars. It has evolved according to the percepts of its duty - to shape the national consciousness fulfilling its important 
social function - to protect the "national interests". Thus the main concern in the historical studies remained the preservation of the national(ist) continuum of the $19^{\text {th }}$ and $20^{\text {th }}$ centuries. Therefore the noted large scale of theoretical isolation is due to the political setting in which the Bulgarian historical discipline is nourished (Todorova, 1992: 1105-1117). Archaeology and classical studies as integral part of Bulgarian historical scholarship has existed and developed in the same setting as an active ideological and political factor.

Notwithstanding the critical approaches to the Bulgarian historiography the antiquity of the Bulgarian past remained perceived as a historical totality that can be uncovered by scrupulous study of sources of different kind combined under the rubric of interdisciplinarity. The image of antiquity is associated today with the Thracians considered to be representative for the so called paleo-Balkan (non-Hellenic) culture which form the foundations of the historical Balkan societies and cultures. Fabricated by academic scholarship of the late socialism this image was coined as ethno-national differentia specifica which shaped worldviews in the popular imagination. The Bulgarian scholarship of antiquity using outdated culture-historical approaches with its attendant doctrines of cultural survivals and cultural continuities coined narrative representations of the "spirituality" of the Bulgarians. They are actively marketed through the politics of commodification after the 1990s. The national imagination is fuelled mainly through the popular mass media and tourist commoditization policy (Lazova, 2014). Thus the image of the Thracian antiquity was produced as a "live message of ancient heritage". The ancient-ness of many material and non-material values were embedded in the national popular culture though different kinds of media which helped to enter as tangible or intangible heritage in the international list of UNESCO. This fact however deprived the education from contemporary notions about the ancient world as a whole.

Antiquity is mostly visualized by archaeology and its practice. As was already noted, European archaeology is the context of the development of the Bulgarian archaeology. The discipline is bounded to documentary outlined history and plays considerable role in cultivating ethnic identities, stimulating nationalist feelings usually flagged as patriotic. Nationally oriented archaeology began its formation about the end of the $19^{\text {th }}$ century when increasing interest in ethnicity begins to use the notion of archaeological culture. It is formed in the context of the Herder's assumption that every people has its own culture. The final touch to the concept of archaeological culture owes its popularity to Gustaf Kossinna (1858-1931). As linguist and researcher of Indo-European culture, the professor of German archaeology developed the theory that a regionally determined ethnicity can be defined by material culture excavated from a site (Trigger, 2008: 232-241). The culture-historical approach supplies the emotional glue for the direct contact with valuable past through different tangible and intangible antiquities. This approach is also known as ethnic archaeology as it is associated primarily with ethnic identifications and "scholarly" methods active in appropriating ancient legacy from politically alien territories. This approach remains vital in many national schools as it is representative for the national narrative used to raise the national self-confidence and pride.

The potentials of culture-historical orthodoxy in Bulgaria were revealed by applying in my studies the "longue durée" perspective. It proved to be fruitful for the Bulgarian case as it helped to analyzing various tendencies of the communicative nature of the passing processes formative for the construction of national identity. Various kinds of antiquities - archaeological materiality or ancient imageries - reveal different dynamics in the contextualized relations between state policies and making sense of antiquity as formative element of the nation. The notions of the "deep" origins of the nation emerge and are adopted with different intensity depending on various factors. The basic characteristics of the national discourse of antiquity is outlined by the specificities of the historical discipline practiced in Bulgaria. 


\section{Activating the knowledge of antiquity from "outside"}

The National Revival project was activated from "outside" by a number of antiquarians attracted by the ancient times on the Balkans. "The Bulgarian XIX century" began to construct its antiquity comparing it with the Greek as a kind of "otherness". The interest in antiquities is recognized not only as important subject of the educational programs but also as ideological resource which stimulates the formation of collective identity (Lilova, 2003: 202). It becomes clear that classical antiquity means also humanistic Bildung and this is a possibility to endorse the European identity.

The period however is marked by an important deficiency - the general histories lack whatever image of the Bulgarians. This absence from the general histories is recognized as a problem of identification and the belonging of the Bulgarians to the civilized world. Looking at his image in the European mirror the Bulgarian sees that the European scholarship is not interested in his existence, he is "nobody" for Europe (Mishkova, 2006: 250-251). This deficiency will enter permanently the intellectual agenda striving for a constant policies to compensate it. Therefore everything potentially able to mobilize and legitimize the Bulgarians as belonging to the European civilized world has been activated. Antiquities now are recognized as a medium to provide the nation with prestigious past that might be presented to the outside world. Therefore the problematic interpretations of ancient artifacts always are able to make up for deficiency declaring that "we have also contributed to the world".

Recognizing antiquity as an instrument for tracing the "deep roots" of the nation is complicated by the Greek influential past. Some scholars realized that not the demonstration of the Greek superiority but the feeling of civilizational "shortage" in the Bulgarians will be difficult to overcome (Mishkova, 2006: 241). Something more, the notions of antiquity would be modeled in relation to the Greek patterns and at the same time competing with them. In the context of this split identity the earliest generation of national revival intelligentsia began to form the image of the national antiquity through the debates in language, ethnogenesis, and church independence. The research of this early interest in antiquity is however evaluated by the scholars as unsystematically and uncritically accumulation of data of various kind eager to represent them as Bulgarian. It is not clear for instance what are the sources for the Indo-European studies during this period shaped 100 years later with more scholarly image. The debate of the ethnogenesis is activated. Forcing the ethnicity as a research topic various regions are beginning to be described revealing the character of its population as autochthonous and thus legitimating its belonging to the past.

At the end of the $19^{\text {th }}$ century when the growing interest in ethnicity started using the concept of archaeological culture, this basic paradigm influenced the Bulgarian context from "outside". Moreover, these academic figures produced knowledge that activated the visibility of the Bulgarians. Among the intellectuals who entered Bulgaria is Konstantin Jirecek (1854-1918) a Czech scholar who came to Bulgaria in 1879 introducing the culture-historical orthodoxy. This was the leading formula for research in Central and Eastern Europe during the 1870s and 1880s. It was a response to the growing awareness of geographical variability in archaeological record and was accompanied by growing nationalism which made ethnicity to appear as most important factor shaping human history (Trigger, 2008: 211). K. Jirecek in practice territorialized the space through archaeological remains considering them to be Bulgarian according the Treaty of SanStephano They were associated with historical events referring to this space in ancient Greek texts. This evidence is supplemented by a range of ethnographic and folklore observations outlining a territory impregnated with survivals which ensure the cultural continuity of the Bulgarians. Thus Jirecek constructed the communicative basis of the most important modern "national" European disciplines. Archaeology as formative for the historical canon is supposed to be considered as a mission to encourage different ethnic groups being part of multinational empires to become able 
to give meaning of their national belonging (Trigger, 2008: 215). According to the analytical model of Miroclav Hroch (1985) it might be noted that the development of the national idea in the space of the Balkans is asynchronic nevertheless it traces one and the same paths. In this context Bulgarian nationalism is considered to be defensive or weak. Its specificity is constructed in the context of already formatted nationalisms and competing with them at the same time (Todorova 2015).

Jirecek spent several years practicing in Bulgaria and organizing the structure of institutions supposing to produce the knowledge about the past in later times. He insisted on exposing the material culture from the past to evoke the national consciousness. Another scholar also from "outside" is W. Tomaschek (1841-1901) who builds up the compendium of the language of the Thracians. The linguistic heritage as crucial for the nation-building was studied in the context of the so-called German-Austrian diffusionism characteristic for the study of the German and Austrian anthropologists. Their expertise was in geography and the leading concept of the interaction of language and culture on a given territory. According to Tomaschek, the language of the Thracians belonged to Indo-European languages. He is considered now as founding father of the construction of Thracology in Bulgaria from the 1970s on.

4. The interwar period: in quest for Bulgarian Volksgeist through "resurrection" of antiquity

From the end of the $19^{\text {th }}$ century till the end of the communist time the attempt to overcome the feeling of civilizational insufficiency is constantly filled with more and more valuable antiquities. The process of transformations of the" traditional space" which was being replaced by the self-imagining Bulgarians generates difficult questions. The political project for constructing and imagining Bulgaria is interwoven with the important question who are the Bulgarians. Answering this question the intellectual milieu produced a mass of writings. A self-stereotypes or "national traits" began to be fabricated in order to outline the "character" and the "spirituality" of the Bulgarians. In parallel it appeared the important question what have the Bulgarians given to the other nations. Antiquity became the main resource of supplying the national pride with the feeling that "we have also contributed to the world".

The first unfolded endeavor to study the National Revival was Ivan Shishmanov's contribution (1862-1928) who realizes that the Bulgarian "grand narrative" lacks a "resurrection of our ancient-ness" (Daskalov, 2013: 47), as it is valued in many European countries. Thus from the 1920 s on a new trend appeared in the efforts the true "national character" to emerge. Accepting mainly German and French approaches to the study of the "psychology of the Bulgarian people" various folklore data enter the national narrative in order to create the image of the nation as organic (biological) body with physical and mental characteristics re-creating in time and space. In this process of substantializiation of culture as a meaningful essence was reified in such a way as to seem irreversible and unchanging in recreating the national identity. The time between the World War I and World War II is associated with the "two national catastrophes" as they were designated in Bulgarian historical science. It was activated by new and more spectacular search for heroes - this time the remote antiquity will become able to evoke feelings of dignity and proud.

The call for a "new revival of antiquity" brings to the stage a new reading of the ancient past. Nayden Sheytanov is among the intellectuals that evoke ancient Greek figures of Orpheus and Dionysos as archetypal deities which lay the foundations of the national philosophy. Influenced by the Romanian nationalism these figures became proclaimed as promoters of Christianity. Sheytanov is in line with the Jirechek's call for publicity of the knowledge of the past in order to evoke national consciousness. He calls for something more important - the knowledge of the past has to become "the bread and the salt" of the Bulgarian everyday life. He outlined also the need of institutionalization of particular studies on antiquity which might be called 
"Trakistiks". His appeal was realized in full capacity by the communist regime of the 1970s and 1980 s a field research of Thracology was institutionalized by the institute of Thracology (Lazova, 2016: 150-159).

\section{The interwar period: The Bulgarian Altertumswissenschaft}

During this period another process became visible: professionalization of archaeology and classical studies. This is a separate research topic but it is important to note here that the professionalized scholarly developments are closely linked with the German Altertumswissenschaft which influenced the whole interwar academic developments. In this context emerged the figures of Bulgarian scholars as Bogdan Filov, Gavrail Katsrov, Ivan Velkov, Janko Todorov, Georgi Michailov etc. At the beginning of the $20^{\text {th }}$ century emerged clearly outlined local areas where scholarly standards were applied in accumulation of data from antiquity and its interpretation. The study of antiquities by that time is from one side accorded with the international standards and from the other side they have to be framed in wider political context. In the beginning of Balkan wars during 1912 the Ministry of Education delegates a task to B. Filov to take the lead of a scholarly mission in Macedonia and in Edrine (Adrianople) district to collect and describe archaeological and ethnographical data. Archaeologist work is associated with that of the ethnologists, historians, linguists. The research is conducted with the assistance of the Bulgarian Army Stuff. In 1915 The Staff organizes a research mission in Macedonia and the Aegean region. During 1917 it organizes a scientific mission in Dobrudja region also. The expeditions lay particular stress on the importance of these territories for the Bulgarian national history. The political context outlined after the World War I is characterized by the Bulgarian lost territories in Western Thrace and its outlet on the Aegean Sea. This fact adds fuel to the Bulgarian-Greek dispute on the Thracian and Greek pasts (Marinov, 2015: 85-86; Lazova, 2016: 162-163).

The academic publications on antiquity activated processes of regional studies in different areas - Northeastern Bulgaria (Ludogorie or Deliorman region), eastern part of the Rhodope mountains and Strandzha region. Antiquity with its materiality and ancient imagery (Orpheus and Dionysos) outlined territories whose antiquities became inseparable from the national narrative. The research practice was mastered by the Bulgarian scholarly milieu educated primarily in German and Austrian universities and then transferred to the native terrain. The studies made visible some regions forming local symbolic meanings which ensures the national uniformity.

\section{The "new" rhetoric in search for origins}

In the second half of the 1940 s and in the 1950s the strong modernizing impulse of the communist national(ist) project intensified the production of knowledge of the remote past. Antiquities - archaeological findings and ancient imageries - started to gain a crucial role in the representative values of the nation. A critical assessment of this transformation is needed as it is realized in the context of the sovietization and marxisation of the Bulgarian historical science including the field of antiquity. Thus alongside with the criticism of the "bourgeois" nationalistic approaches to antiquities, the declared "new" methods of research are framed with the inevitable ideological formulae of the communist regime. Bulgarian scholars criticizing the "bourgeois" methodology of the pre-war scholarship highly appreciated their "love for national history". Thus the Marxist criticism does not alter the notion of the high status of antiquity in the system of national values. The "national(ist) continuum" institutionalized by Bulgarian Altertumswissenschaft in the context of outlining the "national character" in the interwar period now is remarkably reinforced by the "new" rhetoric nourished actively by the Soviet theory of ethnogenesis (Lazova, 2016: 110-124). Methodologically, it re-animated the symbiosis of the romantic ideas and the positivistic approaches of the $19^{\text {th }}$ century typical for the culture-historical 
approaches. It stabilized the ethnic model and ethnicity remained the main focus of research. Thus the coined "new" rhetoric does not change the nature of the social function of antiquity - to supply the nation with prestigious past and unbroken continuity to the present days.

By that time the Soviet conception of ethnos characterized as primordialist and essentialist was officially sanctioned as unproductive in many critical studies (Kohl 1998: 231). It contrasted sharply with the more situational and relational concepts of ethnic identities developed by most Western anthropologists (Barth, 1969; Eriksen, 2010: 1-22). All methodological devices in Bulgaria during the communist regime were supposed to be coordinated with the Soviet scholarship as "the true science" and thus the Bulgarian studies in antiquity remained isolated from the contemporary debates and the new methodological instruments produced by Western scholarship.

During the 1960 s the historical science is obsessed by the notion of expert knowledge revealing "the true history" of the Bulgarians in order to be understood the "essentially Bulgarian" characteristics. This "new" rhetoric includes the notion of reconsidering the "continuity in the Bulgarian historiography". Stigmatizing the pre-war nationalism the communist national(ist) project changed the rhetoric but not the discourse. The need to reveal the ancient-ness of the Bulgarians in its entire capacity appeared. Therefore in the 1960 s the Thracians were canonized as one of the three components of the Bulgarian nation together with the Slavs and ProtoBulgarians (Iliev, 1998; Marinov, 2015). The production of valuable antiquity for the nation was intensified by research programs of academic institutions sponsored by the state. These new trends in the development of the disciplines producing knowledge about ancient past are stimulated by the so called complex national expeditions. They were accomplished in the Rhodope mountains, Dobrudzha region, Strandzha mountain and Western Bulgaria but antiquity was a small section of these research programs. The activities of the complex expeditions are situated in the bordering regions which tended to outline the space of "our national culture". Following older territorializing markers as symbols of antiquity these activities are associated with territories populated by Bulgarians in the beginning of the $20^{\text {th }}$ century. The ambition of encroaching on a fixed geographical and historical locations becomes visible. The crossing of political boundaries and extending the territory of "the Bulgarian culture in antiquity" with "scholarly" methodology becomes a mechanism for promoting nationalistic claims. It is paralleled with another important branch of the Bulgarian scholarship as the linguistic maps in the second half of the $20^{\text {th }}$ century (Guentcheva, 2003). The "new" rhetoric clearly declares our studies as "patriotic", "loyal" and "objective" restricting the "nationalist" discourses to the neighbors (Billig, 1995). Its concerns are to show the "genuine" characteristics of the Bulgarian culture and its remote past. This ambition of the cultural nationalists in practice implicitly imagined the contours of Great Bulgaria framed by the San-Stephano chimera. The transgression of the political borders is in fact evading the official norm. This is a case of "cultural intimacy" which undermines and at the same time implicitly maintains the prestige of the nation-state which tolerates it. This notion opens up the possibility to trace this process of intimization turning the imagined Great Bulgaria into "structural nostalgia" which allows people to protect their collective secrets - the basis of cultural intimacy.

The professionalization of the archaeological research accompanied with interpretative models needed official periodicals and publications. So, Archeologia issued its first number in 1959. The introductory chapters declared two trends to be followed in this professionalization: the "correct formation of true patriotism" and "the investigation and study of archaeological artifacts turning them into attractive tourist projects" (Archeologia, 1960, 1-2). This is the time when the export of ancient Thracian art began in organized exhibitions abroad.

This model of nationally programmed research started its realization when many theoretical paradigms criticize the incapacity of the primordial and essentialist culture-historical approaches to explain various social or cultural processes. The new approaches in humanities and 
social sciences appear in order to discuss wider range of relations between social structures and individuals. The study of antiquity began to move from a ubiquitous culture-historical orthodoxy to more innovative theoretical insights which managed to reveal in reflexive manner how the knowledge about the deep antiquity is produced and how this knowledge is used by the national state. These debates affect by no means the Bulgarian study of antiquity and its culture-historical approaches. Moreover, the research programs carried out by the Bulgarian Academy of Science lavishly sponsored by the state in the 1970s and the 1980 s focuses on an extremely active ideological image. It activated the production of the Bulgarian culture as unity of the "pastpresence-future". It was based exclusively on the culture-historical methodology continuing to search for the "deepest" roots of the "spirituality" of the Thracians which naturally transcended the "essential" Bulgarian culture. Activated by the Soviet theories of ethnogenesis ethnicity gains now a leading position: the academic approaches have to produce ethnically homogeneous community with inherited language, religion and territory - "revivals" that are constantly maintained by the intellectual elite (Hutchinson, 1994).

The period of 1970 s and 1980 s might be defined as floruit of the Bulgarian culturehistorical methodology: The professionalized archaeology needs an interpretative model. It was called "complex studies" producing a compilation of various data from history, linguistics, ethnology supposed to uncover the Thracian culture. The "complex" methodology required unprecedented centralized institutionalization where a United Center of History was established. A separate Institute of Thracology (1972) and a specialized section of Thracian archeology as part of the Archaeological institute with museum (1983) were organized. Thus in practice the Bulgarian archaeology was gradually becoming archaeology of the Thracians. The intensive historicization of the cultural characteristics of the Bulgarians rooted in the Thracian culture was realized by enormous book production about antiquity as important part of historical studies.

This institutionalization outlines a process leading to embedding the high status of the Thracian antiquity in everyday life and in the habitus of the Bulgarians. It turned into powerful resource for national identity and proud of the prolonged national being. A number of publications, congresses, conferences, exhibitions of "Thracian Gold" abroad, spectacular archaeological discoveries marked a process of ubiquitous embedding the values of remote antiquity into everyday popular life. A lot of municipality emblems appeared. The uses of culturehistorical methodology allowed in many cases freely to associate the archaeological findings with ancient imageries produced by ancient Greek authors. It began to be revealed some tendencies of capsulation of a "scientific truth" that a lot of Thracian ancient imageries were "unjustly separated and appropriated" by the Greeks.

The model of regional studies in the 1970s and the 1980s follows the mapping of the territories studied by the complex national programs from the 1960s. It was improved however by the centralized state sponsoring of the large scaled investigations. The period was marked by numerous anniversaries among which the most spectacular of them - the $1300^{\text {th }}$ anniversary of the establishment of the Bulgarian state. The intensive work on "resurrection" of antiquity institutionalized by several academic institutions has to reveal the "unbroken continuum" infusing a new creative spirit of the nation. The state and the academics gave way to a strategy which broadened the complexity of the expeditions from the 1960s focusing exclusively on antiquities producing the continuity of nation's life. Activating older practices the regions of Dobrudzha, (named now with the ancient name Getica), Strandzha-Sakar area and Rhodope mountains they are being revitalized. Eclectic and outdated methodology refreshed with new rhetoric activated the archetypal figures of Orpheus and Dionysos from the pre-war period. They are now associated with a Thracian-Mycenaean period as a sediment in the Homers poetry where Thracians are mentioned. The revitalized figures initiated a quest for royal doctrines, residences, palaces as differentia specifica of the Thracian culture compared with the polis-based society. These findings developed a discourse on the uniqueness of Thracian culture extracted basically from literary 
ancient texts dating from different periods of time. The imagined uniqueness of the Thracians as a centralized territorial monarchy was valorized as closed aristocratic society accessible only to initiates differing in this way from the rest of the known classical world. The imagined uniqueness of the Thracians is constructed mainly in few books - Trakiyskiyat orfizam (Fol, 1986) and Trakiyskiyat Dionis (Fol, 1991; 1994) in two volumes and in a multitude of publications. In practice this book production tolerated by the state politics deprives the academic studies from alternatives. It even deepens the "cultural intimacy" enlarging the scope of the Thracian-ness which produced the image of the "Bulgarian lands in antiquity". This image became representative for the territory inhabited by the Thracians and divided nowadays by multiple modern national states with their own political boundaries. All of them have the right to share the antiquity as "Bulgarian, Rumanian, Albanian lands in antiquity".

The production of this kind of knowledge was controlled by academic figures patronized by the state. They activated also the search for Thracian-ness among the local experts of antiquities. Publishing a lot of their knowledge they supported them by prefacing their publications. This mutual collaboration between local and national experts deprived the publicity from alternative versions of the remote past. A unified collective memories of the past are achieved framing the national consciousness and national identity. The proclaimed notion of supplying the historical studies of antiquity with "truly scientific" methods in fact produced an ideological context for this kind of research. The established in this way authoritarian production of knowledge about ancient past practically enters the role of state control over scholarly activities. Thus every uncertainty or doubt in this continuum is interpreted as threatening the national interests (Hertzfeld, 2005).

The intensive "resurrection" of antiquity and the processes of imbedding it in popular culture paralleled with a total isolation of the Bulgarian study of antiquity from the dynamics of multiple theoretical innovations in the historical studies as a whole. The unreflexive uses of culture-historical approach revealed a new trend in the representations of antiquities which can be seen in the 1990s. The so called changes in Bulgaria after 1989 gave chance to a number of "free" media to be captured by academic "speakers of the past" whose position may be situated between academic rhetoric and political activism. This control in practice deprived the publicity from the critical views of historical sciences including archaeology and classical studies. The omnipresent image of Orpheus provoked even a "social drama" arising from the belief that he is a Thracian hero deprived unjustly from the Bulgarians. The archaeological sites identified through Greek texts as imbued with Thracian essence are included in the heritage industry (Lazova, forthcoming). The increasing interest in the material and non-material past of different communities including the nation contributes to the development of tourist industry. Some influential ethnographies of the heritage show the appearance of ambivalent unions between the market economy and nationalism in various cultural variants (Hamilakis \& Duke, 2009: 15-40).

To conclude, the constructions of "grand discoveries" which fuelled the "grand narratives" useful for the national pride and for the marketing of the ancient heritage, raise many questions. They are mainly on how ancient places are selected for consumption by the state, by the academy, by individuals; in what ways archaeology and classical imageries became heritage which is by its nature a social activity and how they enter the marketplace. If antiquity is nationalized and commodified by the state how do we participate in the contemporary debates in archaeology and classical studies in general. The questions on how to use disciplinary power of professionalization to provoke the ethical debates in these fields are also very important. Enlarging the reflexivity in the studies of our remote past opens up a space for discussing contemporary methods and practices which will contribute easily to draw a line between ideology and epistemology. Therefore as scholars we can and should adopt a critical and self-reflexive stance towards our categories (Brubaker, 2013: 6; Todorova, 2015). It might be noted also that a scholarship of antiquity obsessed with the past distanced the people from their own time denying 
them a place in our world, denying their coevalness, their right to speak for themselves (Fabian, 1983; Danforth, 1984).

\section{Acknowledgements}

I am thankful to NBU policy to tolerate this kind of reflexive studies, publishing my book, a number of articles and conference participations.

The author declares no competing interests.

\section{References}

Barth, F. (1969). Ethnic groups and boundaries. The social organization of culture difference. Boston.

Billig, M. (1995). Banal nationalism. London: Sage.

Brubaker, R., \& Cooper, F. (2000). Beyond "identity". Theory and Society, 29: 1-47.

Brubaker, R. (2013). Categories of analysis and categories of practice: A note on the study of Muslims in European countries of immigration. Ethnic and Racial Studies, 36, 1, 1-8.

Danforth, L. (1984). The ideological context of the search of continuities in Greek culture. Journal of Modern Greek Studies, 2(1), 53-85.

Daskalov, R. (2013). Kak se misli Balgarskoto Vazrajdane. 10 godini po-kasno. Sofia: Izdatelstvo "Prosveta".

Daskalov, R. \& Vezenkov, Al. (Eds.) (2015). Entangled histories of the Balkans. Vol.3: Shared pasts, disputed legacies. Brill, Leiden/Boston.

Detchev, S. (ed.) (2010). V tarsene na Balgarskoto: mreji na natsionalna intimnost (XIX-XXI) [In search for the essentially Bulgarian: Networks of national intimacy $19^{\text {th }}-21^{\text {st }}$ Centuries]. Sofia: BAN.

Eriksen, Th. (2002). Ethnicity and nationalism: Anthropological perspectives. London: Pluto Press.

Fabian, J. (1983). Time and the other. How anthropology makes its object. New York: Columbia University Press.

Fol, A. (1986). Trakiyskiyat orfizam. Sofia: Universitetsko Izdatelstvo.

Fol, A. (1991). Trakiyskiyat Dionis, Vol. 1: Zagrey. Sofia: Universitetsko Izdatelstvo.

Fol, A. (1994). Trakiyskiyat Dionis,Vol. 2: Sabaziy. Sofia: Universitetsko Izdatelstvo.

Guentcheva, R. (2003) Seeing language: Bulgarian linguistic maps in the second half of the twentieth century. European Review of History, 10, 3, 467-485.

Hamilakis, Y. \& Duke, Ph. (2007). Archaeology and capitalism. Walnut Creek, CA, USA: Left Coast Press.

Hamilakis, Y. \& Anagnostopoulos, A. (2009). What is archaeological ethnography. Public Archaeology: Archaeological Ethnographies, 8(2-3), 65-87.

Herzfeld, M. (1997). Cultural intimacy: Social poetics in the nation-state. New York: Routledge.

Hroch, M. (1985). Social preconditions of national revival in Europe: A comparative analysis of social composition of patriotic groups among smaller European nations. Cambridge: Cambridge University Press.

Hutchinson, J. (1994). Modern nationalism. London: Fontana Press.

Iliev, I. (1998). The proper use of ancestors. Ethnologia Balkanica, 2, 7-18. 
Kohl, Ph. (1998). Nationalism and archaeology: On the construction of nations and the reconstruction of the remote past. Annual Review of Anthropology, 27, 223-246.

Lazova, T. (2014). Perperikon entre nature et histoire: les dimensiones multiples d'une site archeolgique et le peysage de identite Bulgare. Etudes Balkaniques: Paysage religious et memoriels en Europe du Sud-Est: visions anciennes, pratique et politiques recentes (pp. 221-247). Paris.

Lazova, T. (2016). Antichnost, archeologia i natsionalno vaobrazjavane. Antropologichni perspectivi [Antiquity, archaeology and national imagination. Anthropological perspectives]. New Bulgarian University, Sofia.

Lazova, T. (forthcoming). Consumption of the past: Constructing antiquity of an archaeological site in Bulgaria and marketing the narrative representations.

Lilova, D. (2006). Vazrojdenskite znachenia na natsionalnoto ime. Sofia: Izdatelstvo Prosveta.

Marcus, G., \& Fisher, M. (1986). Anthropology as cultural critique: An experimental moment in the human sciences. Chicago and London: The University of Chicago Press.

Marinov, Tch. (2015). Ancient Thrace in the modern imagination: Ideological aspects of the construction of Thracian studies in Southeast Europe (Romania, Greece, Bulgaria). In: R. Daskalov \& Al. Vezenkov (Eds.), Entangled histories of the Balkans. Vol. 3. Shared pasts. Disputed legacies Balkan Studies Library, vol. 16 (pp. 10-118). Leiden, Brill, The Netherlands.

Mishkova, D. (2006). Balkanskijat XIX vek. Drugi prochiti. Sofia: Izdatelstvo“Riva”.

Naumovic, Sl. (1998). Romanticists or double insiders? An essay on the origins of ideologised discources in Balkan ethnology. Ethnologia Balkanika, 2, 100-120.

Samah, S. (2007). Imagining nations. Anthropological perspectives. Nexus, $20(1), 4$.

Todorova, M. (1992). Historiography of the countries of Eastern Europe: Bulgaria. American Historical Review, 4, 1105-1117.

Todorova, M. (2015). Is there weak nationalism and is it a useful category. Nation and Nationalism, 21(4), 681-699.

Trigger, B. (2008). A history of archaeological thought. Cambridge: Cambridge University Press. 